\title{
CORONARY ARTERY BYPASS GRAFTING WITHOUT CARDIOPULMONARY BYPASS USING THE OCTOPUS METHOD: RESULTS IN THE FIRST ONE HUNDRED PATIENTS
}

Erik W. L. Jansen, MD

Cornelius Borst, $\mathrm{MD}, \mathrm{PhD}^{\mathrm{c}}$

Jaap R. Lahpor, MD, PhD

Paul F. Gründeman, $\mathrm{MD}, \mathrm{PhD}^{\mathrm{c}}$

Frank D. Eefting, $\mathrm{MD}^{\mathrm{c}}$

Arno Nierich, $\mathrm{MD}^{\mathrm{b}}$

Etienne O. Robles de Medina, MD, $\mathrm{PhD}^{\mathrm{c}}$

Johan J. Bredée, MD, PhD
Objective: Cardiopulmonary bypass and global cardiac arrest enable safe coronary artery bypass grafting but have adverse effects. In off-pump coronary bypass grafting, invasiveness is reduced, but anastomosis suturing is jeopardized by cardiac motion. Therefore the key to successful off-pump coronary bypass grafting is effective local cardiac wall stabilization. Methods: We prospectively assessed the safety and efficacy of the Octopus tissue stabilizer (Medtronic, Inc., Minneapolis, Minn.) in the first 100 patients selected for off-pump coronary bypass via full or limited surgical access. To immobilize and expose the coronary artery, two suction paddles $(-400 \mathrm{~mm} \mathrm{Hg}$ ), fixed to the operating table-rail by an articulating arm, stabilized the anastomosis site. Results: One hundred forty-one grafts $(96 \%$ arterial) were used to create 172 anastomoses (17\% side-to-side), up to 4 per patient, on average 2.3 in the full access group (46 patients) and 1.2 in the limited access group (54 patients). Complications included conversion to cardiopulmonary bypass $(2 \%)$, conversion from limited to full access $(3 \%)$, myocardial infarction $(4 \%)$, predischarge coronary reintervention (2\%), and late coronary reintervention (1\%). Median postoperative length of hospital stay was 4 days (limited access) or 5 days (full access). Rapid recovery allowed $96 \%$ of patients to resume social activities within 1 month. At the 6-month angiographic follow-up, 95\% of anastomoses was patent. At the 2- to 22-month follow-up (mean, 13 months), 98 patients were in Canadian Cardiovascular Society class I and 2 patients were in class II. Conclusion: These results suggest that off-pump coronary artery bypass grafting with the Octopus tissue stabilizer is safe. Early clinical outcome and patency rates warrant a randomized study comparing this methods with conventional coronary bypass grafting. (J Thorac Cardiovasc Surg 1998;116: 60-7)
$\mathrm{T}^{\mathrm{T}}$ raditionally, coronary artery bypass grafting $(\mathrm{CABG})$ is performed with cardiopulmonary bypass $(\mathrm{CPB})$ and global cardiac arrest to create a still and bloodless target site. However, are these modalities necessary in all patients? In the past, only a

From the Heart-Lung Institute, Departments of Cardiopulmonary Surgery, ${ }^{\mathrm{a}}$ Anesthesia, ${ }^{\mathrm{b}}$ and Cardiology, ${ }^{\mathrm{c}}$ Utrecht University Hospital, Utrecht, The Netherlands.

The study was supported by a grant from The Netherlands Heart Foundation (No. 1993/43.028) and the University Hospital, Utrecht (No. 1995/B903).

Received for publication Nov. 24, 1997; revisions requested Jan. 15, 1998; revisions received Feb. 13, 1998; accepted for publication Feb. 13, 1998.

Address for reprints: Erik W. L. Jansen, MD, Heart-Lung Institute, Utrecht University Hospital (Room E03.406), P.O. Box 85500, 3508, GA Utrecht, The Netherlands.

Copyright (C) 1998 by Mosby, Inc.

0022-5223/98 \$5.00+ $0 \quad \mathbf{1 2 / 1 / 8 9 9 4 4}$ few articles have been published concerning bypass surgery on the beating heart ${ }^{1-6}$ and, more specifically, on reoperative surgery ${ }^{7}$ mainly because the opinion has been that cardiac motion jeopardized anastomosis suturing. In addition, the internal thoracic artery (ITA) as a conduit ${ }^{8,9}$ became widely accepted, but this delicate arterial graft requires meticulous anastomosis suturing. Nonetheless,

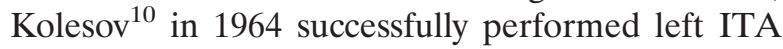
grafting to the left anterior descending artery (LAD) on the beating heart.

Recently, the advent of video-assisted thoracic surgery ${ }^{11}$ has introduced new less-invasive concepts on myocardial revascularization. This included PortAccess $\mathrm{CABG}$ on the arrested heart with $\mathrm{CPB}^{12}$ and on the beating heart without $\mathrm{CPB}$ through limited incisions. ${ }^{13}$ In our opinion, avoiding CPB is the most obvious and important aspect in less invasive CABG. Therefore adequate anastomosis site stabi- 
lization is indispensable. Recently, specific local cardiac wall stabilizers have become available. ${ }^{14,15}$

The objective of this prospective study was to assess the safety and efficacy of the Octopus stabilizer in off-pump CABG. The Octopus tissue stabilizer (Medtronic, Inc., Minneapolis, Minn.) immobilizes and exposes the coronary artery by suction without adverse effects. ${ }^{14}$ The early clinical results (2- to 22-month follow-up) and angiographic outcome (6-month follow-up) are reported in the first 100 patients in whom arterial grafts, predominantly, were used through full and limited surgical access.

\section{Methods}

Between September 1995 and June 1997 in our institution, 1326 patients were operated on for isolated coronary artery disease. One hundred patients (8\%) underwent off-pump complete revascularization with the Octopus method. The preoperative characteristics of the patients are summarized in Table I. In this study patients were included with invalidating angina according to the Canadian Cardiovascular Society (CCS) class III and IV based on (sub)total, occlusive isolated proximal coronary artery disease ( $>70 \%$ angiographic diameter stenosis), refractory to medical treatment, and catheter-based procedures. Patients with unstable angina (Braunwald class IIc and IIIc), with diffuse disease requiring long anastomoses and more than four anastomoses or endarterectomy, or with suspected intramyocardial LAD were excluded. Poor left ventricular function was not an exclusion criterion, except in patients in whom exposure of the target vessel would mean considerable displacement of the heart (e.g., posterior wall exposure through sternotomy access). Posterior wall revascularization was only performed in patients with one dominant circumflex branch. In eight high-risk patients, conventional on-pump CABG procedures were considered contraindicated because of complicated previous cardiac surgery $(n=3)$, poor left ventricular function $(n=2)$, or associated disease $(n=3)$. According to Parsonnet's operative risk stratification, ${ }^{16}$ patients were classified in the following manner: good (74\%), fair $(12 \%)$, poor (11\%), high (3\%), and extremely high $(0 \%)$. Two patients with a left ventricular ejection fraction less than $20 \%$ were operated on with intraaortic balloon pumping. At operation, the following data were sampled on-line event-related and stored in a computer: mean arterial blood pressure, heart rate, cardiac index, mixed venous oxygen saturation, and ST-segment elevation in lead $\mathrm{V}_{5}$. All patients were prepared as for conventional $\mathrm{CABG}$ to enable conversion of strategy any time in bail-out situations. Normothermia was maintained by a warm-water blanket.

Anesthesia. Anesthesia was based on intravenous propofol and high-dose sufentanil-citrate. More recently, in the absence of coagulation disorders, a combination of intravenous propofol and low-dose sufentanil-citrate and thoracic epidural analgesia with bupivacaine $0.5 \%$ was preferred to facilitate perioperative management.
Table I. Patient characteristics*

\begin{tabular}{|c|c|}
\hline & $n$ \\
\hline \multicolumn{2}{|l|}{ Sex } \\
\hline Male & 72 \\
\hline Female & 28 \\
\hline \multicolumn{2}{|l|}{ NYHA class } \\
\hline I & 0 \\
\hline II & 3 \\
\hline III & 89 \\
\hline IV & 8 \\
\hline One-vessel disease & 65 \\
\hline Two-vessel disease & 27 \\
\hline Three-vessel disease & 8 \\
\hline \multicolumn{2}{|l|}{ LVEF } \\
\hline$>40 \%$ & 86 \\
\hline $20 \%-40 \%$ & 12 \\
\hline$<20 \%$ & 2 \\
\hline Not suitable for PTCA & 73 \\
\hline \multicolumn{2}{|l|}{ Previous PTCA } \\
\hline Failed & 15 \\
\hline Restenosis & 12 \\
\hline Hypercholesterolemia & 50 \\
\hline Family history of coronary artery disease & 36 \\
\hline Hypertension & 34 \\
\hline Previous myocardial infarction & 33 \\
\hline Smoking history & 29 \\
\hline Diabetes mellitus & 12 \\
\hline Prior CVA & 8 \\
\hline Previous cardiac surgery & 7 \\
\hline Peripheral vascular disease & 6 \\
\hline Renal insufficiency & 4 \\
\hline Obstructive lung disease & 4 \\
\hline Obesity & 4 \\
\hline
\end{tabular}

NYHA, New York Heart Association; $L V E F$, left ventricular ejection fraction; PTCA, percutaneous transluminal coronary angioplasty; $C V A$, cerebrovascular accident.

*Aged $59 \pm 10$ years (range, 33 to 75 years).

Cardiac wall stabilization. The Octopus tissue stabilizer (Fig. 1) consists of two (left and right) paddles with four or five suction domes each (internal diameter $6 \mathrm{~mm}$ ) with a malleable segment, which allows precise adjustment to the cardiac surface. Each paddle is connected by an articulating arm to the operating table rail or to opposite rails (Fig. 2). The suction paddles are placed close to and parallel to the coronary artery to obtain maximum immobilization and minimum compromise of muscle function. Suction is activated in each paddle separately and fixes the target site once suction is -400 $\mathrm{mm} \mathrm{Hg}$. Additional immobilization in the z-direction was achieved by slight stretching of the intervening epicardium by subtle spreading of the paddles, resulting in residual target motion of about $1 \times 1 \times 1 \mathrm{~mm} .{ }^{14}$ Finally, to expose the target in addition to immobilization both paddles were moved simultaneously and then fixed in this position by freezing the articulating arms. The surgical technique has not yet been reported (unpublished data).

Surgical access and grafts. The surgical access routes and type of grafts used are listed in Table II. 


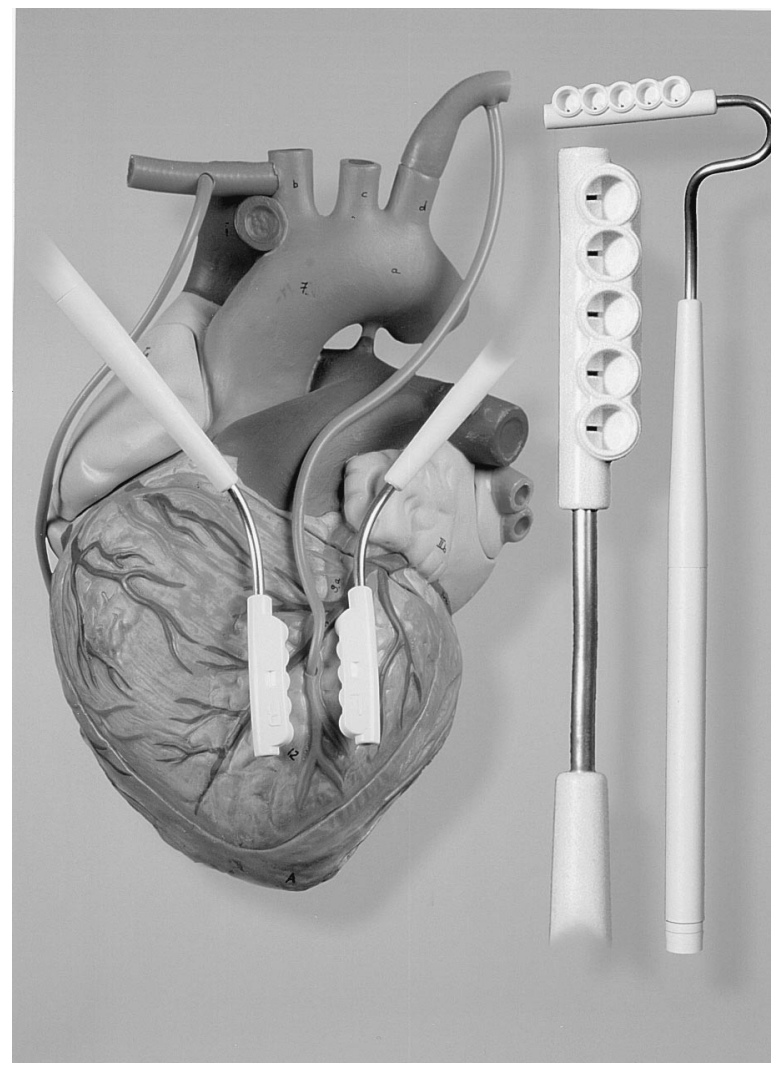

Fig. 1. The Octopus tissue stabilizer. Note the asymmetric configuration and malleable segment for adjustment to the surface of the heart. Both paddles are rigidly connected to the operating table rails by an articulating arm.

Limited access: Small left anterior thoracotomy for onevessel grafting (49 patients, 10 sequential grafts). Initially, the costal cartilage was removed leaving the perichondrium; subsequently the ribs were only spread. The left ITA was dissected to the level of the first intercostal space in the skeletonized fashion. ${ }^{17}$

To maximize access to the target site, one paddle was introduced through the incisional wound and one through a separate stab wound (used later for the drain) between the ribs. Simultaneous displacement of both paddles was essential to expose the diagonal branch for sequential diagonal LAD grafting.

Limited access: Subxiphoid approach for one-vessel grafting of the distal right coronary artery (RCA; four patients) and its proximal posterior descendens branch (one patient). Through a $10 \mathrm{~cm}$ upper midline laparotomy incision, the xiphoid cartilage was excised. After the right gastroepiploic artery had been harvested, grafting was performed with the use of the Octopus to stabilize the target vessel via the wound.

Full access: Median sternotomy, used for two-vessel (25 patients) and three-vessel (8 patients) grafting. The left ITA was dissected in the pedicled fashion; the right ITA was dissected in the skeletonized fashion to obtain more
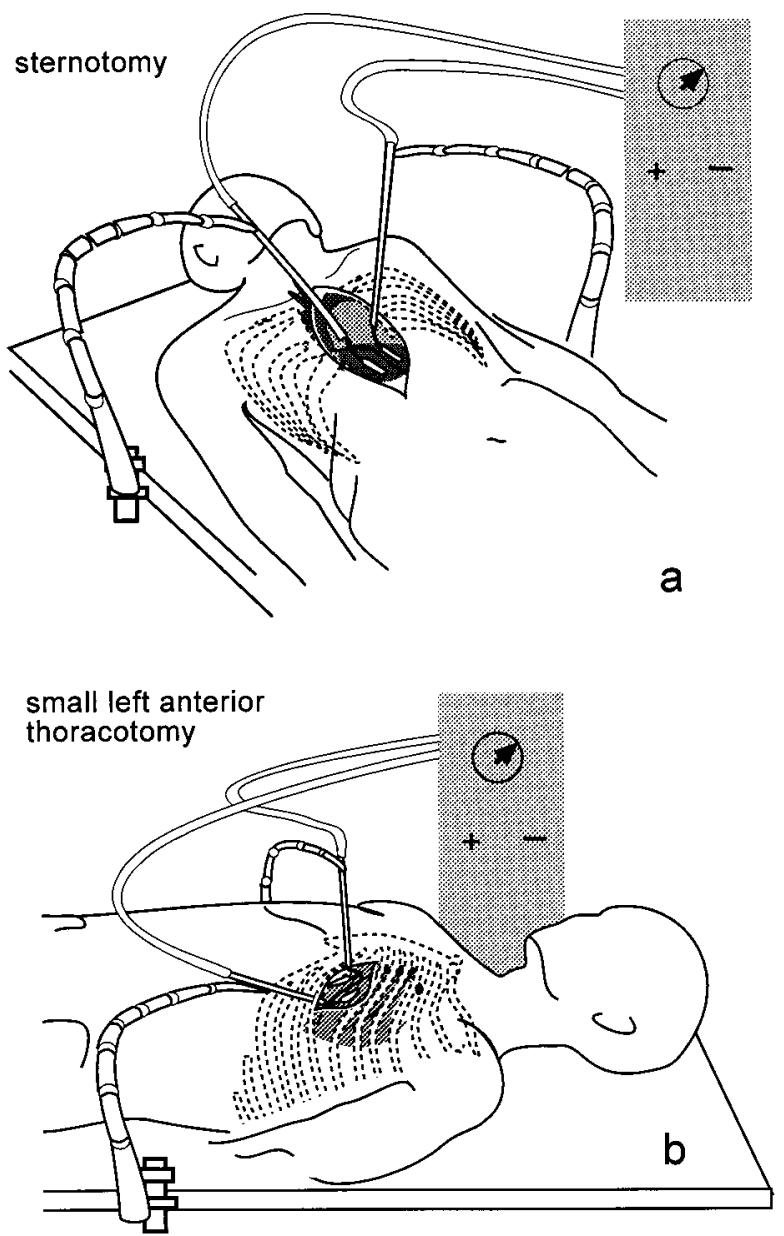

Fig. 2. Surgeon's view. Examples of application of the Octopus tissue stabilizer: a, Through full surgical access for multivessel revascularization. The distal RCA is exposed by the hoisting of the inferior wall. $\mathbf{b}$, Through limited surgical access to expose the LAD and/or diagonal branch. Note that one paddle is installed through a separate stab wound to maximize exposure.

length. The anterior and inferior cardiac wall could then easily be exposed. Posterior wall exposure (tilting of the heart), however, required fluid supplementation and redistribution of blood volume (Trendelenburg maneuver $)^{18,19}$ and sometimes inotropic drug support to maintain adequate cardiac index and arterial blood pressure. The sternotomy approach was also used for one-vessel disease in three obese patients for a single right ITA bypass to the distal RCA and for three sequential diagonal LAD grafts with a wide-angled bifurcation.

Full access: Posterior thoracotomy, used for one-vessel (three patients) and two-vessel (one patient) grafting. The fifth intercostal approach was used for reoperation in three patients in whom sternotomy was considered contraindicated. Because the heart stays in its pericardial cradle, hemodynamics were not compromised. 
Table II. Types of access, grafts, and bypasses used

\begin{tabular}{|c|c|c|c|c|c|}
\hline & $n$ & $\begin{array}{c}\text { No. of } \\
\text { patients }\end{array}$ & $\begin{array}{l}\text { No. of } \\
\text { grafts }\end{array}$ & $\begin{array}{c}\text { No. of } \\
\text { anastomoses }\end{array}$ & Type of bypass \\
\hline \multicolumn{6}{|l|}{ Limited access } \\
\hline \multirow[t]{4}{*}{ Left anterior thoracotomy } & 49 & & & & \\
\hline & & 38 & 38 & 38 & Left ITA-LAD \\
\hline & & 10 & 10 & 20 & Left ITA-DIAG/LAD \\
\hline & & 1 & 1 & 1 & SVG ascending aorta-LAD \\
\hline \multirow[t]{2}{*}{ Subxiphoid } & 5 & & & & \\
\hline & & 5 & 5 & 5 & GEPA-RCA \\
\hline Subtotal & 54 & 54 & 54 & 64 & \\
\hline \multicolumn{6}{|l|}{ Full access } \\
\hline \multirow[t]{12}{*}{ Sternotomy } & 42 & & & & \\
\hline & & 12 & 24 & 24 & Left ITA-LAD + right ITA-RCA \\
\hline & & 9 & 18 & 27 & Left ITA-DIAG/LAD + right ITA-RCA \\
\hline & & 5 & 5 & $10(4)^{*}$ & Left ITA-DIAG/LAD \\
\hline & & 4 & 12 & 12 & Left ITA-LAD + right ITA-OM + GEPA-RCA \\
\hline & & 3 & 3 & 3 & Right ITA-RCA \\
\hline & & 2 & 4 & 4 & Left ITA-LAD + right ITA-OM \\
\hline & & 2 & 4 & 6 & Left ITA-DIAG/LAD + right ITA-OM \\
\hline & & 2 & 6 & 8 & Left ITA-DIAG/LAD + right ITA-OM + GEPA-RCA \\
\hline & & 1 & 1 & $1(1)^{*}$ & Left ITA-LAD \\
\hline & & 1 & 3 & 3 & Left ITA-LAD + SVG Ao-OM + right ITA-RCA \\
\hline & & 1 & 2 & 3 & Left ITA-LAD (LL right ITA-OM $)+$ GEPA-RPD \\
\hline \multirow[t]{5}{*}{ Left posterior thoracotomy } & 4 & & & & \\
\hline & & 1 & 2 & 4 & Left ITA-LAD + SVG descending aorta-PL/OM/ANT \\
\hline & & 1 & 1 & 1 & SVG descending aorta-CX \\
\hline & & 1 & 1 & 1 & SVG descending aorta-OM \\
\hline & & 1 & 1 & 1 & SVG descending aorta-PL \\
\hline Subtotal & 46 & 46 & 87 & 108 & \\
\hline TOTAL & & 100 & 141 & $172 \dagger$ & \\
\hline
\end{tabular}

$D I A G$, Diagonal branch; $S V G$, saphenous vein graft; $G E P A$, right gastroepiploic artery; $O M$, obtuse marginal branch; $A o$, aorta; $R P D$, right posterior descending artery; $P L$, posterolateral branch; $A N T$, anterolateral branch; $C X$, circumflex artery.

*Five anastomoses were constructed after conversion from limited to full access in three patients.

$\dagger 1.7$ per patient.

Note 1: Twenty-four ITA grafts, almost all right ITAs, were used as a free graft, anastomosed to the ascending aorta (23 in the sternotomy group, 1 in the anterior thoracotomy group). One right ITA was used as a Y graft on the left ITA ( $L$ L).

Note 2: One hundred thirty-five arterial conduits and six venous conduits were used.

Distal anastomosis. After treatment with heparin (1.5 $\mathrm{mg} / \mathrm{kg}$ intravenously), the target area was immobilized and exposed. The coronary artery was occluded 5 minutes to evaluate signs of ischemic dysfunction, followed by 5 minutes of reperfusion for preconditioning, before occlusion for constructing the anastomosis. Temporary coronary shunts were not used. The coronary artery was dissected free over $15 \mathrm{~mm}$ to allow a $4 \mathrm{~mm}$ arteriotomy between two atraumatic microvascular clamps (Acland clamps; S \& T Marketing, Neuhausen, Switzerland). The anastomosis was performed with a running polypropylene 8-0 suture with magnifying loupes $(\times 2.5)$.

Revascularization assessment criteria. Electrocardiograms were recorded at least twice during admission, and serial myocardial fractions of creatine kinase (CK-MB) were determined six times up to 48 hours after surgery. Perioperative myocardial infarction was diagnosed in the presence of one or both of the following criteria: (1) myocardial fractions of creatine kinase levels above 50 IU and (2) the development of new Q waves. Bypass graft angiography was performed on the day before discharge in the first 10 patients. The graft quality was assessed by two independent observers, using the thrombolysis in myocardial infarction (TIMI) classification. ${ }^{20}$ In the case of a disagreement, a discussion led to mutual concensus. At 6 months, all patients were scheduled for angiography.

Follow-up. The mean follow-up time was 13 months (range, 2 to 22 months). Follow-up information was collected through direct patient contact and from the referring cardiologist. Clinical outcome according to the CCS was assessed, including electrocardiography and exercise testing at 3 and 6 months.

Statistical analysis. All data are presented as mean \pm standard deviation or as median and range. An unpaired Student $t$ test was used to compare intraoperative mean values for limited and full access.

\section{Results}

Immobilization and exposure of the target site by the Octopus tissue stabilizer allowed accurate suturing, even performing of an occasional patch angio- 
Table III. Operative data

\begin{tabular}{|c|c|c|c|}
\hline & $\begin{array}{l}\text { Limited } \\
\text { access* }\end{array}$ & $\begin{array}{c}\text { Full } \\
\text { accesst }\end{array}$ & $\begin{array}{c}p \\
\text { Value }\end{array}$ \\
\hline Arterial grafts & $53(98 \%)$ & $82(94 \%)$ & \\
\hline Total distal anastomoses & 64 & 108 & \\
\hline With arterial grafts & $63(98 \%)$ & $101(94 \%)$ & \\
\hline $\begin{array}{l}\text { Sequential anastomoses } \\
\text { per graft }\end{array}$ & $10(16 \%)$ & $22(19 \%)$ & \\
\hline $\begin{array}{l}\text { Anastomoses per patient } \\
\quad \text { (aver) }\end{array}$ & 1.2 & 2.3 & \\
\hline $\begin{array}{l}\text { Left ITA harvesting time } \\
\text { (min) }\end{array}$ & $44 \pm 13$ & $22 \pm 10$ & $<0.0001$ \\
\hline $\begin{array}{l}\text { Right ITA harvesting } \\
\text { time (min) }\end{array}$ & - & $21 \pm 9$ & \\
\hline Anastomosis time (min) & $22 \pm 9$ & $15 \pm 7$ & $<0.003$ \\
\hline $\begin{array}{l}\text { Immobilization/presentation } \\
\text { time per anastomosis } \\
\text { (min) } \ddagger\end{array}$ & $48 \pm 13$ & $34 \pm 10$ & $<0.0001$ \\
\hline Surgery time (min) & $185 \pm 45$ & $220 \pm 40$ & $<0.0001$ \\
\hline \multicolumn{4}{|l|}{ Conversion } \\
\hline To CPB & 1 & $1 \S$ & \\
\hline To full access & 2 & - & \\
\hline \multicolumn{4}{|c|}{$\begin{array}{l}* n=54 \text { patients. } \\
\dagger n=46 \text { patients. } \\
\ddagger \text { Including coronary artery preparation time, } 5 \text { minutes preconditioning } \\
\text { ischemia and } 5 \text { minutes reperfusion. }\end{array}$} \\
\hline
\end{tabular}

plasty of the anastomosis site in three patients as the result of underrated coronary artery disease. The operative data are summarized in Table III. Inadvertent detachment of the suction paddles did not occur while the anastomosis was being sutured. Prompt treatment of false air suction by longitudinal or axial adjustment of the paddle to the epicardium was essential.

Bleeding of a suction hematoma ${ }^{14}$ requiring suturing was necessary once in 1720 lesions $(0.06 \%$ of 172 anastomoses with $2 \times 5 \times 172$ lesions). Within 10 minutes, the lesions began to resolve. Temporary segmental occlusion of the coronary artery only occasionally caused 1 to $2 \mathrm{~mm}$ ST segment elevation, which lasted a few minutes. The effect of local cardiac wall immobilization by suction is reflected in Table IV. Intraoperative continuous inotropic drug support (dopamine, $>2 \mu \mathrm{g} / \mathrm{kg}$ ) was necessary in 34 patients (34\%), whereas only 10 patients (10\%) still required this therapy on leaving the operating room. Conversion to $\mathrm{CPB}$ was necessary in two patients $(2 \%)$. One patient with two-vessel disease and chronic atrial fibrillation did not tolerate temporary occlusion of the RCA. The procedure was converted to $\mathrm{CPB}$ without aortic crossclamping. In three patients, a sternotomy was performed in addition to anterior thoracotomy because of underrated LAD pathologic findings in combination with conduit length. In one of these patients, grafting was done on CPB.

With respect to the harvesting of the arterial conduits, damage to the left ITA occurred three times (all female patients) early in the series. It was repaired in two cases.

Postoperative course. In most patients, recovery was fast and uneventful. Ninety-seven patients were extubated within the first hours after surgery, and their intensive care unit stay was 24 hours.

Complications. The median peak myocardial fractions of creatine kinase was 10 units/L (range, 2 to 257 units/L). Myocardial infarction occurred in four patients (4\%), requiring intraaortic balloon pumping for low cardiac output in two patients. Myocardial infarction related to the grafted vessel occurred in one patient in whom conversion to sternotomy was necessary. One patient required percutaneous transluminal coronary angioplasty of an ungrafted artery (identification error) and a 5-day continuation of preoperatively initiated intraaortic balloon pumping as the result of intraoperative myocardial infarction. One patient had prolonged respiratory insufficiency as the result of kyphoscoliosis with extremely restricted lung function. Reversible ischemic neurologic deficits occurred in two patients with preexisting cerebrovascular insufficiency, in whom a free ITA anastomosis had been performed on the ascending aorta. One of these two patients had also been converted to CPB. None of the patients experienced mental disorders. In 5 of the first 10 patients in the anterior thoracotomy group, an early pericarditis was observed electrocardiographically, probably related to a dry gauze pad that was used to improve exposure. The median postoperative length of hospital stay was 4 days in the limited access group and 5 days in the full access group. Within 1 month after surgery, $96 \%$ of patients had resumed their premorbid activities. The postoperative data are summarized in Table V.

Early graft patency. In 15 patients, in whom angiography was performed before discharge (10 by protocol, 5 by indication), all 24 anastomoses were patent. In one patient, however, distal tapering of the right ITA required revision into a free graft, again performed off-pump with the Octopus method.

Follow-up. There was a $100 \%$ complete followup. At $13 \pm 11$ months (range, 2 to 22 months), one patient is using antianginal medication and 98 patients were in CCS class I. There was one late successful balloon angioplasty of an anastomosis 
Table IV. Hemodynamic changes during immobilization and presentation of target vessel by the Octopus tissue stabilizer

\begin{tabular}{|c|c|c|c|c|}
\hline & \multirow{2}{*}{$\begin{array}{l}\text { Limited access: } \\
\text { anterior wall } \\
\quad(n=49)\end{array}$} & \multicolumn{3}{|c|}{ Full access } \\
\hline & & $\begin{array}{l}\text { Anterior wall } \\
\quad(n=39)\end{array}$ & $\begin{array}{l}\text { Inferior wall } \\
\quad(n=32)\end{array}$ & $\begin{array}{c}\text { Posterior wal } \\
\quad(n=12)\end{array}$ \\
\hline \multicolumn{5}{|l|}{ Heart rate (beats $/ \mathrm{min}^{-1}$ ) } \\
\hline Before Octopus & $66 \pm 11$ & $65 \pm 12$ & $69 \pm 12$ & $66 \pm 12$ \\
\hline During Octopus & $70 \pm 11$ & $75 \pm 14$ & $74 \pm 14$ & $77 \pm 11$ \\
\hline After Octopus & $70 \pm 12$ & $72 \pm 13$ & $74 \pm 13$ & $77 \pm 12$ \\
\hline \multicolumn{5}{|c|}{ Mean arterial pressure $(\mathrm{mm} \mathrm{Hg})$} \\
\hline Before Octopus & $72 \pm 9$ & $74 \pm 11$ & $72 \pm 11$ & $73 \pm 13$ \\
\hline During Octopus & $70 \pm 11$ & $70 \pm 12$ & $67 \pm 10$ & $66 \pm 15$ \\
\hline After Octopus & $70 \pm 11$ & $69 \pm 10$ & $68 \pm 8$ & $60 \pm 15$ \\
\hline \multicolumn{5}{|c|}{ Cardiac index $\left(\mathrm{L} \cdot \mathrm{min}^{-1} \cdot \mathrm{m}^{-2}\right)$} \\
\hline Before Octopus & $3.3 \pm 1.1$ & $2.6 \pm 0.5$ & $2.9 \pm 0.6$ & $2.8 \pm 0.6$ \\
\hline During Octopus & $3.1 \pm 0.9$ & $2.5 \pm 0.4$ & $2.6 \pm 0.6$ & $2.8 \pm 0.5$ \\
\hline After Octopus & $3.1 \pm 0.9$ & $2.6 \pm 0.4$ & $2.5 \pm 0.5$ & $3.1 \pm 0.7$ \\
\hline \multicolumn{5}{|l|}{ Dopamine required } \\
\hline During Octopus (\%) & $7(14)$ & $9(23)$ & $10(31)$ & $8(67)$ \\
\hline
\end{tabular}

Data of subxiphoid and left posterior access group not included. "During Octopus" and "after Octopus" data represent, respectively, measurements 5 minutes after having completed and "freezed" presentation. Data are mean \pm standard deviation.

site. An internal defibrillator was implanted in a patient with sustained ventricular tachycardia without residual ischemia, in the presence of preexistent poor left ventricular function.

Graft flow. Doppler flow signal detection was inconsistent.

Exercise testing. Six-month exercise testing was performed in $92 \%$ of patients, including the three patients who refused recatheterization. Signs of ischemia were present in two patients.

Six-month angiography. Six-month follow-up angiography was performed in 86 of 100 patients(86\%), representing 147 of 172 anastomoses. Of these, nine anastomoses could not be visualized because of selective injection of the grafts (four right gastroepiploic arteries, two free ITAs, and two right ITAs) failed. The overall patency rate was $95 \%$. One hundred eighteen anastomoses had a TIMI grade-3 full flow; 10 had a grade- 2 flow; 4 had a grade- 1 flow, and 6 were occluded. All single left ITA grafts to the LAD were patent.

\section{Discussion}

Off-pump CABG is facilitated most by mechanical stabilization, whether by pressure or by suction fixation, each with specific applications. Excellent results have been reported with single left ITA grafting to the LAD via anterior thoracotomy in a large series, ${ }^{13}$ based on retractor-mounted pressure fixation. The principal findings of this study are as follows: (1) The Octopus method immobilized all major coronary arteries well at the anastomosis site without adverse effects, reflected in a $95 \%$ patency rate; (2) the median hospitalization was relatively short (4 to 5 days), and social activities were resumed within 1 month; and (3) at the 2- to 22-month follow-up, 98 patients were in the CCS class I. Suction fixation can be used to immobilize and expose the target area, whether with the use of anterior thoracotomy (including 16\% sequential grafts diagonal branch/LAD), subxiphoid approach or thoracotomy, and sternotomy for two- and threevessel grafting, and future, truly minimally invasive, Port-Access. ${ }^{14}$ Via sternotomy access, exposure of the anterior wall and inferior wall is well tolerated hemodynamically (Table IV); therefore it may also be considered in patients with poor left ventricular function. Exposure of the posterior wall was tolerated, provided dislocation was performed slowly (approximately 1 minute). Fluid redistribution (Trendelenburg maneuver) ${ }^{19}$ or administration and some inotropic drug support (dopamine in 67\% of patients) helped to maintain arterial pressure. Thus, left ventricular dysfunction seems to be a relative exclusion criterion. The Octopus tissue stabilizer has no permanent adverse effects on the underlying myocardium or on a coronary branch when it happens to pass just beneath one of the suction cusps. ${ }^{14}$ However, we prefer to avoid this. It is independent of surface irregularities, fatty tissue, and application 
Table V. Postoperative data (0 to 22 months' follow-up)

\begin{tabular}{|c|c|c|}
\hline & $\begin{array}{c}\text { Limited } \\
\text { access } \\
(n=54 \mathrm{pts})\end{array}$ & $\begin{array}{c}\text { Full } \\
\text { access } \\
(n=46 p t s)\end{array}$ \\
\hline Deaths & 0 & 0 \\
\hline Operative myocardial infarction & 2 & 2 \\
\hline Low output requiring IABP & 0 & 2 \\
\hline \multicolumn{3}{|l|}{$\begin{array}{l}\text { Reinterventions during admission } \\
\text { for }\end{array}$} \\
\hline Bleeding & 0 & 0 \\
\hline Revision of anastomosis* & 0 & 1 \\
\hline PTCA of ungrafted vessel $\dagger$ & 0 & 1 \\
\hline $\begin{array}{l}\text { Reversible ischemic neurologic } \\
\text { deficit }\end{array}$ & 1 & 1 \\
\hline Paroxysmal atrial fibrillation & 5 & 7 \\
\hline Acute non-infectious pericarditis $\ddagger$ & 8 & 0 \\
\hline Pleural effusion & 5 & 4 \\
\hline Gastrointestinal bleeding & 0 & 1 \\
\hline Wound infection & 1 & 0 \\
\hline Use of blood products (pts) & 5 & 13 \\
\hline $\begin{array}{l}\text { Postoperative hospital stay } \\
\text { (days, mean } \pm \text { SD and } \\
\text { median, range) }\end{array}$ & $\begin{array}{c}4.5 \pm 0.5 \\
(4,2-8)\end{array}$ & $\begin{array}{l}6.7 \pm 6.6 \\
(5,3-44)\end{array}$ \\
\hline Readmissions & $8 \S$ & $1 \dagger$ \\
\hline $\begin{array}{l}\text { Coronary reinterventions after } \\
\text { initial discharge }\end{array}$ & $1 \|$ & 0 \\
\hline
\end{tabular}

*Revision of right ITA to the RCA, because of too much tapering of the distal graft.

$\dagger$ Patient with poor left ventricular function.

¥Five patients were among the first 10 patients; see §.

$\S$ Four patients for pain associated with pericarditis.

|Balloon angioplasty of anastomosis site.

site (ventriculoventricular [e.g., LAD] or atrioventricular [e.g., RCA]).

While still applying the traditional CABG procedure in most of the patients, the new stabilizers allow surgeons to tailor CABG treatment individually to the patient. In our institution, the percentage of off-pump CABG with the use of the Octopus tissue stabilizer has increased to $12 \%$ in 1997. This percentage reflects patient selection according to our inclusion and exclusion criteria and, moreover, an active catheter-based program in our institution.

Advantages of off-pump bypass surgery. Offpump bypass surgery conserves the blood constituents, avoids global myocardial ischemia, preserves the interventricular septal function, ${ }^{21}$ and may avoid neuropsychologic deficits caused by malperfusion, microemboli from $\mathrm{CPB}$, and atheromatous emboli from manipulation of the aorta. ${ }^{22}$ In our experience no stroke with a permanent deficit occurred. The rapid psychosomatic recovery of the patients was striking. Postoperative length of hospital stay was reduced by 2 to 3 days in our institution. Cognitive functions appeared to be well preserved in these patients but were not formally tested. Moreover, off-pump CABG reduced the need for blood products; in this series only $18 \%$ of patients needed blood products, on average two units, which may be further reduced with the use of a cell salvage device. The incidence of paroxysmal atrial fibrillation was low (12\%), compared with on-pump $\mathrm{CABG}^{23}$ but contrary to our expectation the problem was not totally abolished. Undoubtedly, there is morbidity, reflecting the learning curve (for example, the acute sterile pericarditis leading to early readmissions). The results justify off-pump CABG to be considered in patients with associated disease, especially cerebrovascular insufficiency and renal insufficiency ${ }^{6}$ and also in the very elderly patients in whom in-hospital mortality rates may be as high as $11.5 \% .^{24}$

Limitations. Patients with diffuse coronary artery disease requiring long anastomoses and multiple $(>4)$ grafts and with intramyocardial LAD are unsuitable candidates. The globally arrested heart allows more time-efficient bypass grafting compared with the installation of a stabilizer for each vessel separately.

The decisive factor in the acceptance of off-pump CABG will be the early angiographic patency rate. At 6 months, the patency rate of the single left ITA-LAD graft was $100 \%$. Overall, $95 \%$ of anastomoses were angiographically patent at 6 months. Most failures were found in side-to-side anastomoses (of the diagonal branch) and reflected a learning curve. The standard of comparison will be on-pump CABG with the left ITA to the LAD as single-vessel $\mathrm{CABG}^{25}$ and multivessel $\mathrm{CABG}^{26,27}$ with a longterm $96 \%$ patency rate of the left ITA. $^{9}$ With arterial grafts, in this series $96 \%$, favorable longterm patency may be expected. Alternatively, catheter-based interventional techniques are evolving, but their long-term results in multivessel disease are unknown. By reducing the restenosis rate, stenting may become increasingly competitive. ${ }^{28,29}$ Although there is a learning curve for this type of CABG on the beating heart, the initial results are encouraging and seem cost effective. Randomized studies have been initiated in our institution to compare offpump CABG with the Octopus tissue stabilizer to conventional $\mathrm{CABG}$ with $\mathrm{CPB}$ and to stenting.

Conclusion. By effective local cardiac wall immobilization, the Octopus tissue stabilizer facilitated limited and full-access CABG without CPB for selected patients with single- and multiple-vessel disease. Randomized trials seem warranted. 


\section{Addendum}

Patient 79, a 74-year-old man, died because of intracerebral bleeding after repeat 6-month angiography, with all grafts fully patent. This is an exceptional complication, but it still proves that even angiography may lead to fatal complications.

We thank H. Wesenhagen, MD, H.J. Mansvelt Beck, J.P. van der Brugge, T. Maikoe, J. de Witte, G. van Aarnhem, MD, and R. Meijer for their assistance.

\section{REFERENCES}

1. Ankeney JL. To use or not to use the pump oxygenator in coronary bypass operations. Ann Thorac Surg 1975;19:108-9.

2. Trapp WG, Bisarya R. Placement of coronary artery bypass graft without pump oxygenator. Ann Thorac Surg 1975;19: $1-9$.

3. Benetti FJ, Naselli G, Wood M, Geffner L. Direct myocardial revascularization without extracorporeal circulation: experience in 700 patients. Chest 1991;100:312-6.

4. Buffolo E, Andrade JCS, Branco JNR, Aguiar LF, Teles CA, Gomes WJ. Coronary artery bypass grafting without cardiopulmonary bypass. Ann Thorac Surg 1996;61:63-6.

5. Pfister AJ, Zaki MS, Garcia JM, Mispireta LA, Corso PJ, Qazi AG, et al. Coronary artery bypass without cardiopulmonary bypass. Ann Thorac Surg 1992;54:1085-92.

6. Moshkovitz Y, Lusky A, Mohr R. Coronary artery bypass without cardiopulmonary bypass: analysis of sort-term and mid-term outcome in 220 patients. J Thorac Cardiovasc Surg 1995;110:979-87.

7. Fanning WJ, Kakos GS, Williams TE. Reoperative coronary artery bypass grafting without cardiopulmonary bypass. Ann Thorac Surg 1993;55:486-9.

8. Loop FD, Lytle BW, Cosgrove DM, Stewart RW, Goormastic M, Williams GW, et al. Influence of left internal mammary artery graft on 10 year survival and other cardiac events. N Engl J Med 1986;314:1-6.

9. Cameron A, Davis KB, Green G, Schaff HV. Coronary bypass surgery with internal-thoracic-artery-grafts: effects on survival over a 15-year period. N Engl J Med 1996;334:216-9.

10. Kolesov VI. Mammary artery-coronary artery anastomosis as method of treatment for angina pectoris. J Thorac Cardiovasc Surg 1967;54:535-44.

11. Landreneau RJ, Mack MJ, Hazelrigg SR, Dowling RD, Acuff TE, Magee MJ, et al. Video-assisted thoracic surgery: basic technical concepts and intercostal approach strategies. Ann Thorac Surg 1992;54:800-7.

12. Stevens JH, Burdon TA, Peters WS, Siegel LC, Pompili MF, Vierra MA, et al. Port-access coronary artery bypass grafting: a proposed surgical method. J Thorac Cardiovasc Surg 1996;111:556-66.

13. Calafiore AM, Di Giammarco G, Teodori G, Bosco G, D'Annunzio E, Barsotti A, et al. Left anterior descending coronary artery grafting via left anterior small thoracotomy without cardiopulmonary bypass. Ann Thorac Surg 1996;61: 1658-65.

14. Borst C, Jansen EWL, Tulleken CF, Gründeman PF, Mansvelt Beck HJ, van Dongen JWF, et al. Coronary artery bypass grafting without cardiopulmonary bypass and without interruption of native coronary flow using a novel anastomosis site restraining device ('Octopus'). J Am Coll Cardiol 1996; 27,1356-64.

15. Boonstra PW, Grandjean JG, Mariani M. Improved method for direct coronary artery grafting without $\mathrm{CPB}$ via anterolateral small thoracotomy. Ann Thorac Surg 1997;63:567-9.

16. Parsonnet V, Dean D, Burnstein ED. A method of uniform stratification of risk for evaluating the results of surgery in acquired adult heart disease. Circulation 1989;79(suppl): $1-12$.

17. Jansen EWL, Mansvelt Beck HJ, Gründeman PF, Bredée JJ. Facilitated exposure of the internal mammary artery in MICABG surgery. Ann Thorac Surg 1997;63:1797-9.

18. Jansen EWL, Gründeman PF, Mansvelt Beck HJ, Heijmen RH, Borst C. Experimental off-pump grafting of a circumflex branch via sternotomy using a suction device. Ann Thorac Surg 1997;63:S93-6.

19. Gründeman PF, Borst C, van Herwaarden JA, Mansvelt Beck HJ, Jansen EWL. Hemodynamic changes during displacement of the beating heart by the Utrecht 'Octopus' method. Ann Thorac Surg 1997;63:S88-92.

20. The TIMI study group. The thrombolysis in myocardial infarction (TIMI) trial: phase I findings. N Engl J Med 1985;312:932-6.

21. Akins CW, Boucher CA, Pohost GM. Preservation of interventricular septal function in patients having coronary artery bypass grafts without cardiopulmonary bypass. Am Heart J 1984;107:304-9.

22. Mahanna EP, Blumenthal JA, White WD, Croughwell ND, Clancy CP, Smith LR, et al. Defining neuropsychological dysfunction after coronary artery bypass grafting. Ann Thorac Surg 1996;61:1342-7.

23. Aranki SF, Shaw DP, Adams DH, Rizzo RJ, Couper GS, VanderVliet M, et al. Predictors of atrial fibrillation after coronary artery surgery: current trends and impact on hospital resourses. Circulation 1996;94:390-7.

24. Peterson ED, Cowper PA, Jollis JG, Bebchuk JD, DeLong ER, Muhlbaier LH, et al. Outcomes of coronary artery bypass graft surgery in 24461 patients aged 80 years or older. Circulation 1995;92(suppl):II85-91.

25. Ovrum E, Tangen G, Holen EA. Facing the era of minimally invasive coronary grafting: current results of conventional bypass grafting for single-vessel disease. Ann Thorac Surg 1997;64:159-62

26. Berreklouw E, Schönberger JPAM, Ercan S, Koldewijn E, de Bock M, Verwaal VJ, et al. Does it make sense to use two internal thoracic arteries? Ann Thorac Surg 1995;59:1456-63.

27. Grandjean JG, Voors AA, Boonstra PW, den Heyer P, Ebels T. Exclusive use of arterial grafts in coronary artery bypass surgery for three vessel disease. J Thorac Cardiovasc Surg 1996;112:935-42.

28. Serruys PW, de Jaegere PPT, Kiemeneij F, Macaya C, Rutsch $\mathrm{W}$, Heyndrickx G, et al. A comparison of balloon expandable-stent implantation with balloon angioplasty in patients with coronary artery disease. New Engl Med J 1994;33:48995.

29. Pocock SJ, Henderson RA, Rickards AF, Hampton JR, King $\mathrm{SB}$, Hamm CW, et al. Meta-analysis of randomized trials comparing coronary angioplasty with bypass surgery. Lancet 1995;346:1184-9. 